\title{
KEBIASAAN MAKAN BEBERAPA JENIS IKAN PELAGIS DI PERAIRAN TELUK TOMINI
}

\author{
Suwarso", A. Zamrony"), dan Rahmat Setiawan")
}

\begin{abstract}
ABSTRAK
Studi tentang kebiasaan makan ikan pelagis di Teluk Tomini telah dilakukan berdasarkan pada hasil pengamatan terhadap isi lambung ikan contoh yang tertangkap di sekitar rumpon pada bulan Juli sampai dengan Agustus 2003 dan bulan Agustus 2004 di Teluk Tomini. Hasil menunjukkan preferensi terhadap suatu jenis makanan berbeda-beda untuk tiap spesies yang terlihat dari perbedaan komposisi mangsa dan frekuensinya. Ikan malalugis (Decapterus macarellus, Carangidae) dan banyar (Rastreliger kanagurata, Scombridae) adalah ikan pemakan plankton; sedangkan katombo (Selar crumenophthalmus, Carangidae) memakan jevenil ikan dan udang. Di pihak lain, selain cumi-cumi, ikan pelagis besar (yellowfin tuna, cakalang (K. pelamis), dan tongkol (Euthynnus spp.)) memakan berbagai jenis ikan pelagis, ikan karang, serta udang Keragaman preferensi terhadap berbagai jenis mangsa tersebut menggambarkan suatu hubungan di antara tingkatan tropik, namun interaksi antar spesies dan komunitas plankton sebagai komponen dasar belum diketahui.
\end{abstract}

\begin{abstract}
Feeding habits of the pelagic fishes in Tomini Bay. By: Suwarso, A. Zamrony, and Rahmat Setiawan

Study on feeding habits of the pelagic fishes in Tomini Bay was carried out based on the examination of guts contains of the fishes caught around the rumpon at July-August 2003 and August 2004 in Tomini Bay. Result shows the preference of the fish for the foods is different for each and other as well as far. Composition of prey and its frequency. Malalugis (Decapterus macarellus, Carangidae) and banyar are absolutelly plankton feeder: katombo (Selar crumenophthalmus, Carangidae) consumes the juveniles and shrimps. In the other hand, the large pelagic fishes eat many pelagic fishes, rock fishes and shrimps. The divers of preference to the preys can explain the trophic relationship among the tropic levels; however, the interspeces relationships on the basic components of plankton community are unknown yet.
\end{abstract}

KEYWORDS: $\quad$ feeding habit, pelagic fish, Tomini Bay

\section{PENDAHULUAN}

Dalam kesatuan WPP Teluk Tomini, Laut Maluku, dan Laut Seram potensi sumber daya pelagis diperkirakan 486.000 ton per tahun atau kira-kira $83 \%$ dari rata-rata total produksi periode tahun 1997 sampai dengan 2002; dari jumlah itu sebagian besar di antaranya $(80 \%)$ berupa ikan pelagis kecil (Anonymous, 2001). Berdasarkan pada survei hidroakustik biomassa ikan pelagis di Teluk Tomini (lahan seluas $59.000 \mathrm{~km}^{2}$ ) sampai dengan kedalaman $150 \mathrm{~m}$ diduga 221.914 ton yang terdiri atas ikan pelagis besar $63 \%$ dan sisanya $(37 \%)$ ikan pelagis kecil (Natsir et al., 2005; Dalam terbitan ini). Ikan pelagis kecil terutama diupayakan dengan pukat cincin mini dan menjangkau sampai dengan kedalaman $80 \mathrm{~m}$; sedangkan ikan pelagis besar ditangkap dengan menggunakan pancing tuna atau handline (untuk yellowfin tuna ( $T$. albacares. Thunnus albacares)), huhate atau pool and line (untuk cakalang, Katsuwonus pelamis) dan jaring insang atau gill net (untuk tongkol (Euthynnus spp.) dan tenggiri); teknologi pancing tuna saat ini menjangkau sampai dengan kedalaman $150 \mathrm{~m}$ (Fayakun et al., 2005; Dalam terbitan ini). Jenis-jenis yang dominan tertangkap pukat cincin antara lain malalugis, solisi

Peneliti pada Balai Riset Perikanan Laut, Jakarta
(Rastrelliger kanagurta, Scombridae), katombo, dan jenis-jenis lainnya (Clupeidae); ikan-ikan muda dari tuna, cakalang ( $K$. pelamis), tongkol juga cukup banyak tertangkap (Hariati et al., 2005; Dalam terbitan ini).

Ikan malalugis memberi kontribusi paling besar dalam hasil tangkapan ikan pelagis kecil (63 sampai dengan $85 \%$ ) oleh pukat cincin; sedangkan yellowfin tuna dan cakalang merupakan target penangkapan nelayan pancing. Ikan pelagis tersebar hampir di seluruh kawasan perairan, daerah penangkapan pukat cincin, pancing tuna, dan huhate pada umumnya bersamaan, yaitu di sekitar rumpon yang juga tersebar luas di seluruh perairan (Fayakun et al., 2005; Dalam terbitan ini). Tulisan ini membahas hasil kajian tentang kebiasaan makan beberapa jenis ikan pelagis yang tertangkap di sekitar rumpon berdasarkan pada pengamatan terhadap isi lambung ikan contoh. Hasil kajian diharapkan dapat bermanfaat untuk menjelaskan sifat bioekologi tiap spesies kaitannya dengan tropic level khususnya di perairan ini serta biological process perairan. Study tentang sifat biologi lainnya dilaporkan oleh Andamari \& Zubaidy (1994), Andamari \& Hutapea (2003), Sumadiharga (1993), Suwarso et al. (2000), Suwarso et al. (2005, Dalam terbitan ini). 


\section{BAHAN DAN METODE}

Contoh lambung ikan dikumpulkan secara acak bersamaan dengan pengambilan contoh biologi (komposisi spesies, komposisi ukuran, dan maturity) melalui survei darat tahun 2004 di tempat pendaratan ikan di Gorontalo, Parigi, dan Marisa; jumlah contoh per kelas panjang dipertimbangkan sama (proporsional). Ikan contoh diambil dari hasil tangkapan nelayan; ikan malalugis, solisi, dan katombo (ikan pelagis kecil) diambil dari pukat cincin sedangkan madidihang atau yellow fin tuna, cakalang dan tongkol (ikan pelagis besar) masing-masing diambil dari pancing tuna, huhate, dan jaring. Spesimen lambung diawet dengan larutan formalin $10 \%$ untuk pengamatan lebih lanjut, kecuali untuk lambung ikan tuna.

Pengamatan isi lambung ikan mengikuti prosedur seperti yang diterangkan oleh Holden \& Raitt (1974). Pengamatan plankton yang terdapat dalam lambung ikan (plankton feeder) meliputi identifikasi jenis (genus) dan jumlah individu (sel) setiap jenis. Penghitungan fitoplankton menggunakan Sedgewick Rafter Counting Cell (kapasitas $1 \mathrm{ml}$ ) melalui metode sapuan, yaitu mencacah seluruh jenis plankton yang ditemukan dalam air contoh; ulangan 2 kali. Identifikasi jenis plankton dilakukan berdasarkan pada Yamaji (1996). Untuk ikan tuna, cakalang, dan tongkol, pengamatan dilakukan secara langsung di lapangan dengan cara mengidentifikasi dan menghitung seluruh mangsa yang ditemukan dalam lambung. Analisis secara grafis diterapkan untuk melihat kecenderungan-kecenderungan yang terjadi. Karena seringkali mangsa (ikan) yang ditemui dalam lambung ikan pelagis besar sudah hancur, penghitungan dilakukan berdasarkan pada frekuensi kehadirannya dalam lambung.

\section{HASIL DAN BAHASAN}

Masing-masing 3 spesies ikan pelagis kecil dan pelagis besar diamati isi lambungnya untuk studi ini, yaitu malalugis, solisi, katombo, tuna sirip kuning ( $T$. albacares), cakalang dan tongkol; jumlah contoh yang diamati untuk tiap spesies masing-masing: malalugis 40 spesimen (ukuran 18 sampai dengan $25 \mathrm{~cm}$ ), solisi 25 spesimen (ukuran 19 sampai dengan $26 \mathrm{~cm}$ ), katombo 20 spesimen (ukuran 17 sampai dengan 22 $\mathrm{cm})$, tuna 65 spesimen, cakalang 25 spesimen (ukuran 30 sampai dengan $55 \mathrm{~cm}$ ), dan tongkol 20 spesimen (ukuran 31 sampai dengan $48 \mathrm{~cm}$ ). Dari sejumlah 65 spesimen lambung tuna yang diamati 46 di antaranya berasal dari kelompok ikan muda (ukuran 17 sampai dengan $61 \mathrm{~cm}$ ), sedangkan lainnya berupa ikan tuna dewasa ukuran 101 sampai dengan $122 \mathrm{~cm}$.

\section{Kebiasaan Makan Ikan Pelagis Kecil}

Hasil pengamatan terhadap contoh lambung ke-3 spesies ikan pelagis kecil yang dikumpulkan memperlihatkan adanya perbedaan dalam komposisi jenis makanan pada tiap spesies beserta frekuensinya masing-masing. Hal ini, menunjukkan bahwa setiap spesies memiliki preferensi yang berbeda terhadap suatu jenis makanan tertentu sehingga dengan demikian tiap spesies mungkin menempati tingkatan tropik (tropic level) yang berbeda pula. Komposisi jenis organisme yang dimakan tiap spesies terlihat pada Gambar 1. Ditemukan 5 kelompok jenis organisme yang dimakan ikan malalugis di mana 3 jenis di antaranya memiliki kontribusi paling besar, yaitu Diatom, Copepode, dan udang (Crustacea), masing-masing sekitar $53 \%, 20 \%$, dan $16 \%$; jenis lainnya terdiri atas Dinoflagellata (zooplankton) dan kelompok lainnya (sisik ikan dan mata ikan). Pada

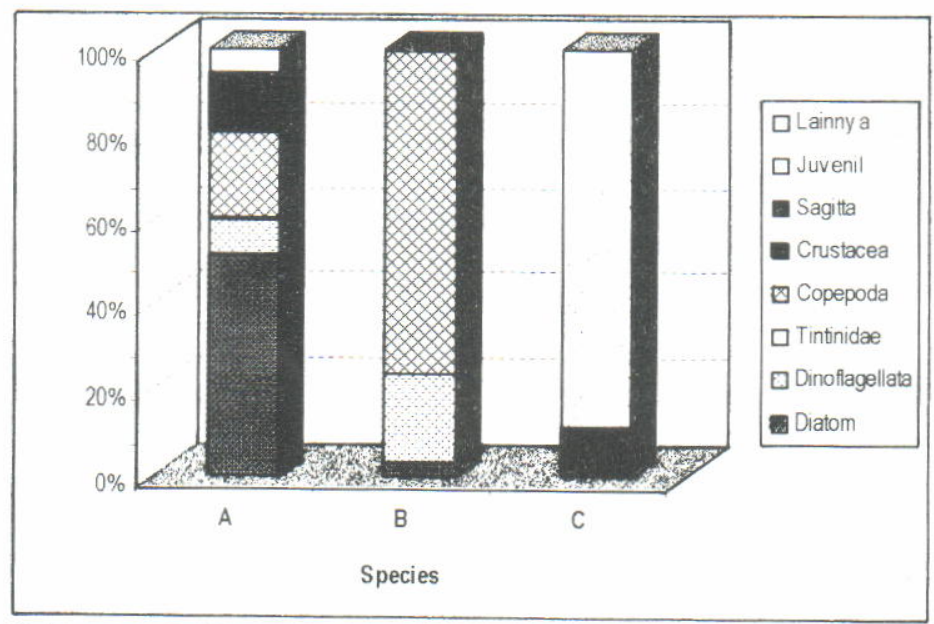

Keterangan: (A: D. macarellus; B: R. kanagurta; dan C: $S$. crumenophthalmus)

Remarks: (A: D. macarellus; B: R. kanagurta; and C: S. crumenophthalmus)

Gambar 1. Komposisi makanan 3 jenis ikan pelagis kecil yang tertangkap di sekitar rumpon di Teluk Tomini bulan Juli sampai dengan Agustus 2003

Figure 1. Food composition of three small pelagic fishes caught around the rumpon in Tomini Bay on 
solisi, kelompok Copepode (zooplankton) memberi kontribusi paling besar sekitar $81 \%$, lainnya terdiri atas Dinoflagellata dan Diatom; sedangkan makanan pada katombo terutama berupa juvenil ikan ( $92 \%$ ) dan udang.

Dari hal tersebut, di atas diketahul bahwa 2 spesies ikan pelagis kecil, malalugis, dan solisi, cenderung merupakan ikan pemakan plankton (plankton feeder); sedangkan katombo cenderung bersifat carnivora. Pada malalugis kontribusi plankton kira-kira $81 \%$ yang terdiri atas Diatom 53\% dan zooplankton (Dinoflagellata dan Copepode) $28 \%$ sedangkan pada solisi hampir keseluruhan makanan $(98 \%)$ berupa plankton dan terdiri atas Copepode $76 \%$, Dinoflagellata $20 \%$, dan Diatom 3\%. Kelompok Crustacea yang dimakan malalugis (kira-kira 14\%) merupakan meroplankton udang rendah atau juvenil udang yang belum diketahui jenisnya.

Diatom merupakan kelompok fitoplankton yang menjadi dasar dalam piramida makanan dan menjadi makanan utama bagi konsumen primer seperti Copepode (zooplankton) dan ikan-ikan herbivora seperti malalugis dan Clupeidae. Berdasarkan pada hal tersebut, dapat diduga bahwa kehidupan 2 spesies ini (menyangkut distribusi, kelimpahan, makanan, dan reproduksi) memiliki ketergantungan yang lebih besar pada distribusi dan kelimpahan plankton serta kesuburan perairan. Malalugis merupakan ikan oseanik yang menyebur sangat luas di perairan Indonesia timur termasuk sekitar Sulawesi. Di Teluk Tomini jenis ini tersebar hampir di seluruh perairan dan menjadi target penangkapan nelayan pukat cincin, namun kelimpahannya diduga semakin tinggi di wilayah perairan sebelah timur (sekitar mulut teluk) terutama di sekitar Bulaemo (Kabupaten Banggai, Sulawesi Tengah) yang menjadi lokasi tujuan penangkapan nelayan Gorontalo dan nelayan lokal (Hariati et al., 2005; Dalam terbitan ini). Di wilayah perairan yang berdekatan (Bunta, Ampana) juga sangat melimpah. Malalugis tertangkap sepanjang tahun, peningkatan hasil tangkapan mulai terjadi pada bulan Juli (musim timur) dan mencapai puncaknya sekitar bulan Oktober sampai dengan Nopember (Hariati et al., 2005; Dalam terbitan ini); pada bulan Desember sampai dengan Januari (musim barat) hasil tangkapan rendah. Hal-hal tersebut sangat cocok dengan dugaan eksisnya perairan sekitar Bualemo sebagai region upwelling pada musim timur sehingga perairan menjadi sangat subur (Amri et al., 2005; Dalam terbitan ini) dan memiliki kepadatan plankton tinggi (Awwaludin et al., 2005; Dalam terbitan ini). Kesuburan perairan dan kepadatan plankton tinggi diikuti oleh kepadatan ikan yang tinggi pula. $\mathrm{Di}$ samping itu, ketersediaan makanan yang cukup melimpah di sekitar region upwelling diduga melatarbelakangi proses biologis biota laut lainnya. Hasil studi biologi reproduksi oleh Suwarso et al. (2005, Dalam terbitan ini) menunjukkan hal yang bersesuaian; kepadatan plankton (sebagai makanan juvenil) yang tinggi (mulai) pada musim timur diperkirakan menjadi alasan terjadinya puncak musim pemijahan yang diduga berlangsung mulai bulan Juli sampai dengan September; pada bulanbulan tersebut gonad index mencapai minimum karena ikan-ikan dewasa matang telur (mature atau ripe gonad) keluar dari perikanan untuk berpijah (spawning migration).

Berbeda dengan 2 spesies ikan terdahulu, sebagai ikan carnivora katombo terutama memakan juvenil ikan dan udang. Penyebaran dan kelimpahan spesies ini berlawanan dengan malalugis, yaitu makin ke arah barat semakin banyak (Hariati ot al., 2005; Dalam terbitan ini). Perbedaan pola makan yang disesuaikan dengan pola distribusi kelimpahan organisme mangsa serta sifat biologi lainnya diperkirakan menjadi alasan perbedaan penyebarannya

\section{Kebiasaan Makan Ikan Pelagis Besar}

Berbeda dengan kelompok ikan pelagis kecil, ikan pelagis besar pada umumnya bersifat sebagai ikan carnivora (pemangsa). Cumi-cumi yang umum ditemukan dalam lambung ikan kemungkinan besar berasal dari umpan yang digunakan nelayan; pada tuna frekuensi kehadirannya $66 \%$, sedangkan pada cakalang dan tongkol masing-masing $77 \%$ dan $73 \%$. Frekuensi kehadiran (\%) tiap jenis mangsa pada ke-3 spesies disajikan pada Tabel 1. Berdasarkan pada frekuensi kehadirannya dalam seluruh contoh yang diamati diperoleh perbedaan komposisi jenis organisme mangsa pada ke-3 spesies seperti diperlihatkan pada Gambar 2.

Dalam lambung yellowfin tuna ditemukan berbagai jenis ikan pelagis kecil, cakalang, ikan karang (buntal), dan udang. Jenis-jenis ikan pelagis kecil yang dapat diidentifikasi antara lain teri, layang, selar, dan lemuru. Kelompok ikan merupakan bahan yang sudah hancur. Terdapat perbedaan preferensi makanan dari kelompok yuwana (panjang 17 sampai dengan $40 \mathrm{~cm}$ atau bobot 0,3 sampai dengan $1,8 \mathrm{~kg}$ ) dan ikan dewasanya (panjang 60 sampai dengan 122 $\mathrm{cm}$ atau bobot 5 sampai dengan $30 \mathrm{~kg}$ ). Selain cumicumi, yuwana lebih menyukai ikan (termasuk petek), teri dan udang; kelompok ikan ini terdiri atas ikan pelagis kecil seperti layang, selar, lemuru, serta petek. Jenis-jenis ikan pelagis tersebut diduga juga menjadi makanan utama ikan dewasa; selain itu ikan dewasa ukuran 101 sampai dengan $122 \mathrm{~cm}$ (bobot 20 sampai dengan $29 \mathrm{~kg}$ ) juga memakan ikan buntal dan cakalang. Tidak ditemui udang dalam lambung ikan dewasa, udang hanya ditemui dalam lambung yuwana.

Frekuensi kehadiran kelompok ikan, ikan teri dan udang paling tinggi, masing-masing $45 \%, 34 \%$, dan $28 \%$. Di antara ikan pelagis kecil lainnya, Decapterus memiliki frekuensi kehadiran paling tinggi (13\%). Yellow fin tuna dan cakalang diduga juga berinteraksi dengan habitat karang, yang terlihat dari sebagian kecil mangsanya berupa ikan karang kecil (ikan 
Tabel 1. Frekuensi kehadiran (\%) tiap jenis mangsa pada yellowfin tuna, cakalang, dan tongkol di perairan Teluk Tomini pada bulan Agustus 2004

Table 1. Frequency of occurence (\%) of the preys in yellowfin tuna, cakalang, and tongkol in Tomini Bay on August 2004

\begin{tabular}{lccc}
\hline \multicolumn{1}{c}{ Preys Species } & T. albacares & K. pelamis & Euthynnus \\
\hline Cumi-cumi (umpan) & 66 & 77 & 73 \\
Ikan & 45 & 18 & 73 \\
Layang & 13 & - & - \\
Selar & 4 & 14 & - \\
Siro & 4 & - & - \\
Teri & 34 & 18 & - \\
Cakalang & 2 & - & - \\
Ikan Buntal & 4 & - & - \\
Cumi-cumi & 6 & 5 & - \\
Udang & 28 & - & 64 \\
Lain-lain & 4 & 4 & - \\
\hline
\end{tabular}

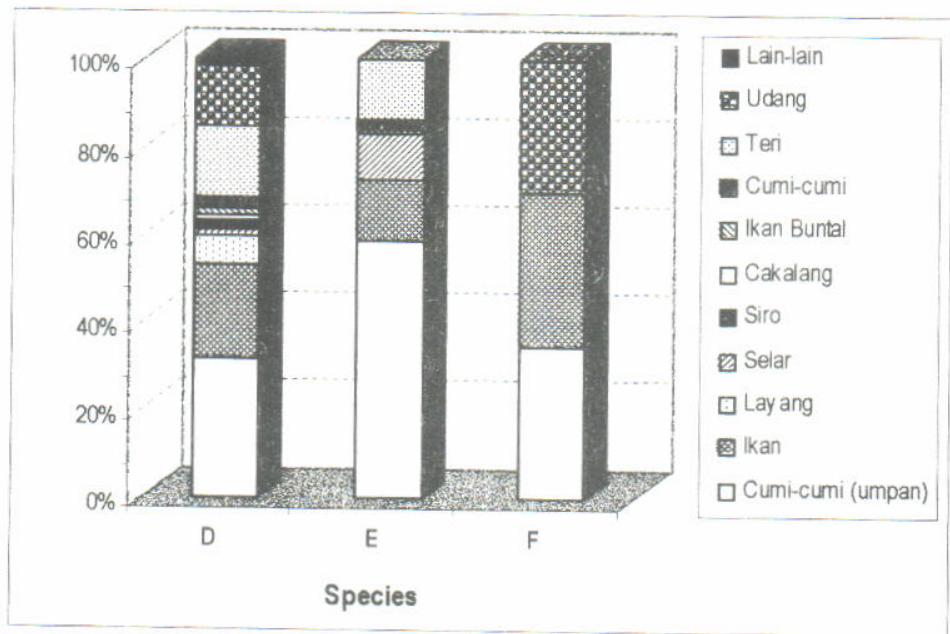

Gambar 2. Komposisi makanan (\% kehadiran) 3 jenis ikan pelagis besar yang tertangkap di sekitar rumpon di Teluk Tomini pada bulan Agustus 2004.

Figure 2 $\quad$ Keterangan: (D: T. albacares; E: K. pelamis; dan F: Euthynus sp.) Figure 2. Food composition of three large pelagic fishes caught around the rumpon in Tomini Bay on
August 2004 .

Remarks: (D: T. albacares; E: K. pelamis; and F: Euthynus sp.)

buntal). Selain cumi-cumi dan petek, kelompok ikan pelagis kecil diduga juga merupakan mangsa yang penting bagi cakalang. Ikan teri memberi kontribusi cukup besar, frekuensi kehadirannya $18 \%$. Sedangkan pada tongkol, selain cumi-cumi, ikan pelagis kecil dan udang diperkirakan juga merupakan mangsa yang penting, frekuensi kehadirannya masing-masing sekitar $73 \%$ dan $64 \%$.

\section{Keterkaitan antar Tingkatan Tropik}

Keragaman preferensi terhadap berbagai jenis makanan tersebut di atas menggambarkan suatu keterkaitan yang sangat jelas di antara spesies yang masing-masing menempati suatu tingkatan tropik (tropic level) tertentu dan secara keseluruhan bersama dengan komunitas plankton membangun suatu jaring-jaring makanan dengan kepentingan yang berbeda-beda di antara tingkatan tropik. Diatomae (fitoplankton) sebagai produsen primer utama merupakan makanan bagi konsumen primer yang berupa zooplankton (misalnya Copepode, Tintinidae, dan Dinoflagellata) serta ikan-ikan herbivora seperti malalugis, solisi, dan Clupeidae yang juga memangsa Copepode, Tintinidae, dan Dinoflagellata. Ikan-ikan pelagis kecil selanjutnya dimangsa ikan pelagis besar seperti tuna, cakalang, dan tongkol. Di pihak lain, udang yang kemungkinan merupakan pemangsa meroplankton juga akan dimangsa oleh malalugis dan katombo serta tuna dan tongkol. Variasi dalam jenis mangsa secara musiman dari tiap spesies belum diketahui.

Secara global, mudah dipahami bahwa pada akhirnya seluruh tingkatan tropik sangat bergantung pada rantai paling dasar yang berupa fitoplankton 
yang pada gilirannya untuk keseluruhan proses kehidupannya ditentukan oleh ketersediaan nutrien. Perairan yang kaya nurtrien adalah perairan yang subur. Oleh karena itu, terkait dengan dugaan potensi upwelling di sekitar Bualemo (Banggai) suatu kajian sistem produksi di wilayah ini dapat menjadi alternatif dalam pengkajian stok ikan.

\section{KESIMPULAN}

1. Malalugis dan solisi termasuk pemakan plankton, sedang katombo adalah karnivora. Ikan pelagis besar (tuna, cakalang, dan tongkol) pada umumnya karnivora, memangsa berbagai jenis ikan pelagis kecil yang diduga merupakan mangsa penting bagi jenis-jenis tersebut. Udang, teri dan yuwana ikan juga merupakan mangsa yang penting bagi ikan-ikan tersebut. Madidihang dimungkinkan juga berinteraksi dengan lingkungan karang Kepulauan Togian.

2. Diduga terdapat keterkaitan antara komunitas plankton dengan kelompok ikan pelagis kecil (layang, solisi, katombo, dan lemuru) dan selanjutnya ikan pelagis besar (madidihang, cakalang, dan tongkol) yang dimungkinkan menggambarkan suatu jaring-jaring makanan dan sekaligus saling ketergantungannya satu sama lain.

\section{DAFTAR PUSTAKA}

Anonymous. 2001. Pengkajian stok ikan di perairan Indonesia. Pusat Riset Perikanan Tangkap. Badan Riset Kelautan dan Perikanan. Departemen Kelautan dan Perikanan. Pusat Penelitian dan Pengembangan Oseanologi. Lembaga IImu Pengetahuan Indonesia. Jakarta. 125 pp.

Amri, K., Suwarso, \& Herlisman. 2005. Dugaan upwelling berdasarkan analisa komparatif citra sebaran suhu permukaan laut dan klorofil-a di perairan Teluk Tomini. Jurnal Penelitian Perikanan Indonesia Vol.11 No.6 Tahun 2005. Dalam terbitan ini. Jakarta

Andamari, R. \& T. Zubaidi. 1994. Some aspects of reproductive biology of Decapterus Macarellus in Banda Island, Maluku. Presented in the Workshop on Biology, Dynamic and Exploitation of the Small Pelagic Fishes in the Java Sea. Bogor, 21-22 March 1994. Java Sea Pelagic Fishery Assessment Project.

Andamari, R. \& J. H. Hutapea. 2003. The reproductive biology of yellowfin tuna (Thunnus albacares) from the Indian Ocean. Papers International Seminar on Marine and Fisheries. Jakarta,15-16 December 2003.
Awwaludin, Suwarso, \& Rahmat S. 2005. Distribusi kelimpahan dan struktur komunitas plankton pada musim timur di perairan Teluk Tomini. Jurnal Penelitian Perikanan Indonesia Vol.11 No.6 Tahun 2005. Dalam terbitan ini. Jakarta.

Fayakun, S., Erfind N., \& Suwarso. 2005. Profil perikanan Teluk Tomini. Jurnal Penelitian Perikanan Indonesia Vol.11 No.6 Tahun 2005. Dalam terbitan ini. Jakarta.

Hariati, T., Suwarso, \& A. Zamrony. 2005. Perikanan pelagis kecil di Teluk Tomini. Jurnal Penelitian Perikanan Indonesia Vol.11 No.6 Tahun 2005. Dalam terbitan ini. Jakarta.

Herlisman \& Suwarso. 2005. Profil fisik massa air Teluk Tomini. Jurnal Penelitian Perikanan Indonesia Vol.11 No.6 Tahun 2005. Dalam terbitan ini. Jakarta.

Holden, M. J. \& D. F. S Raitt (eds.). 1974. Manual of fisheries sciences. Part 2. Methods of resource investigation and their application. FA.O Fish. Tech. Pap., (115). Rev. 1: 214 p.

Natsir, M., Wudianto, \& B. Sadhotomo. 2005. Pendugaan biomassa ikan pelagis di perairan Teluk Tomini dengan metoda akustik bim terbagi (split beam acoustic system). Jurnal Penelitian Perikanan Indonesia Vol.11 No.6 Tahun 2005. Dalam terbitan ini. Jakarta.

Retno A. \& John H. H. 2003. The reproductive biology of yellowfin tuna (Thunnus aibacares) from the Indian Ocean. Papers International Seminar on Marine and Fisheries. Jakarta,15-16 December 2003.

Sumadiharga, K. 1993. Reproduksi dan makanan ikan momar putih (Decapterus macrosoma) di Teluk Ambon. Seminar Nasional Biologi XI. Ujung Pandang.

Suwarso, Dharmadi, \& J. Widodo. 2000. Biology and fishery of malalugis biru, mackerel scad, Decapterus macarellus, in North Sulawesi waiers of Indonesia. Proc. JSPS-DGHE Int. Symposilim on Fisheries Science in Tropical Area. 552-557

Suwarso, T. Hariati, \& A. Zamroni. 2005. Dugaan pemijahan dan biologi populasi malalugis atau mackerel scads (Decapterus macarellus, CARANGIDAE) di Teluk Tomini. Jurnal Penelitian Perikanan Indonesia Vol.11 No.6 Tahun 2005. Dalam terbitan ini. Jakarta.

Yamaji, I. 1996. Illustration of the marine plankton of Japan. Hoikusha. Japan. 
